\title{
Liberals, Communitarians, Republicans and the Intervention of the State in the Private Sphere
}

\author{
Rafael Rodrigues Pereira \\ Federal University of Goias
}

\begin{abstract}
The aim of this paper is to discuss whether the increasing intervention of the state in the private sphere-as is evidenced in labor laws, consumer rights, bioethics, and Internet crimes-is compatible with the liberal ideal of neutrality, or, on the contrary, whether it can be seen as a turning point towards the position of communitarian or republican authors, for whom the state must endorse a substantive good. Such a turning point could lead to a reformulation of the public and private spheres, and of course, raise questions over which values justify which kinds of intervention. This paper will cover these debates in three parts: First, by presenting briefly the history of the liberal conception of rights, I will try to show that, from a starting point based mostly on individual protection, the liberal tradition has become more interventionist, which can be seen through the notion of "claim rights." Departing from John Rawls's work, I will argue that this notion allows for some level of intervention, without betraying liberal neutrality. Subsequently, I will discuss the difference between this kind of intervention and the ones proclaimed by communitarians and republicans authors: The former will be illustrated by Michael Sandel's criticism of Rawls in Liberalism and the Limits of Justice, and the later by Richard Dagger's position in Civic Virtues, Citizenship, and Republican Liberalism. Finally, in the third part, we'll discuss whether liberal principles can be harmonized with the republican and communitarian focus on civic virtues and good life.
\end{abstract}

Keywords: State intervention, liberalism, communitarianism, republicanism, neutrality, public sphere, private sphere

\section{Introduction}

It's possible to see the contemporary phenomenon of the state's increasing intervention in the private sphere - as evidence in labor laws, consumer rights, bioethics, and Internet crimes — as directly related to the debate, in political philosophy, among liberals, republicans, and communitarians. One of the most important issues discussed in this context is the neutrality of the state: Should government actions favor some conception of the good life? Or should their actions be based only on the conception of justice, which would be, theoretically, independent and prior to such conceptions? If this latter view is associated to the liberal tradition, and if we understand "neutrality" to mean refraining from intervening in people’s private lives, then this recent phenomenon could reflect a trend toward republican or communitarian views. However, this conclusion could

Rafael Rodrigues Pereira, university professor, Ph.D. in Philosophy (PUC-RJ) and Lecturer, Department of Philosophy, Federal University of Goiás (UFG), Brazil; main research fields: Ethics (especially Contemporary Virtue Ethics) and the Liberal-communitarian Debate. Email: rafarodrigues252@gmail.com. Brazil.

This paper was done with the support of the Conselho Nacional de Desenvolvimento Científico e Tecnológico-Cnpq- 
potentially be too hasty, if we are able to conceive of some kind of "intervention" as being compatible with liberal ideals. Further, if it is possible, how can we ascertain if this contemporary trend is related to a liberal view, or, on the contrary, to communitarian or republican views? And how could all those different values coexist in the same society? This paper will address these issues.

\section{Liberal Interventions}

Traditionally, liberalism comprises two main characteristics: a) a strong emphasis on liberty and individual rights and b) the neutrality of the state. A good way to understand what "neutrality" means in this context is through John Rawls's formulation of the "priority of the just:" The just is not derived from the good. Therefore, the state must be neutral in regard to conceptions of the good life (Rawls 1999, 26).

This neutrality is criticized, predominately, by republican and communitarian authors, who stress the importance of the virtues and the common good, which presupposes, of course, some conception of the good (Sandel 1998, IX; Dagger 1997, 175).

An interesting way to put this is to say that the key-concept of liberalism is autonomy, but not virtue. Autonomy, here, is understood as self-government, which, as Richard Dagger argues, is not directly connected to a conception of the "good," as the notion of virtue is (Dagger 1997, 14; 17).

The emphasis on autonomy has always been an essential aspect of the liberal conception of rights. John Locke clearly conceives "rights" as a way to protect individual freedom-hence autonomy—against the arbitrary interventions of others. ${ }^{1}$ However, this individualistic notion has acquired, especially during the 20th century, a more stressed social dimension, establishing a type of relationship between people. The distinction, made by Wesley Hohfeld, between claim rights and liberty rights, makes this point very clear: The autonomous individual is understood as an author of claims upon others. As Dagger puts it, the ancient notion of "natural rights" proceeds from the idea of self-possession, but contemporary "human rights," though a direct descendant of the later, rests on the conception of "a person as a being with needs and interests that must be met if he or she is to live a full human life” (Dagger 1997, 22).

This "social" conception of rights paves the way for a more interventionist state. A good example is Rawls's principle of difference, which can be seen as endorsing a claim right: Rawls thinks that the "least advantaged" members of society have the right to be somehow compensated for their bad luck in the natural and social lottery (Rawls 1999, 86). In this sense, the state can, for instance, tax the more fortunate-who don't deserve their good luck - in order to assist the less fortunate. This is, of course, a kind of intervention. The interesting point, however, is whether it is compatible with liberal neutrality.

Libertarian authors, such as Robert Nozick, believe that it is not compatible with liberal neutrality: If we understand autonomy as a kind of self-possession, then it implies, for Nozick, the possession of our abilities (or “natural assets”) and our holdings, being a product of our work (Nozick 1974, 224). That means that taxing people's revenues is an illegitimate appropriation of people's ownership, ergo a disrespect of their rights. Nozick compares taxing to stealing and forced labor (Nozick 1974, 169). This position is clearly related to liberalism's origins, when, as we say, the main purpose of “rights" is to protect individual's autonomy against external interventions.

Authors like Rawls—sometimes called "liberal egalitarians"-disagree. However, their disagreement is not about the necessity of protecting autonomy. On the contrary, their conception is also centered on this notion (if it was not, we would not call them "liberals"). Consequently, the difference between the views must be 
understood as a different treatment of autonomy, more consonant to the relational dimension of contemporary rights.

This treatment is very well grasped by Will Kymnlicka’s discussion: He stresses the difference between “formal” and "substantive" self-ownership. Let’s imagine, for instance, a very poor person who desperately needs a job. The employer will be in a position to offer him a very low salary. Should this be considered as a “voluntary transaction?” For libertarians, like Nozick, the answer is yes. As Kymnlicka argues, they have a formal conception of autonomy, narrowly connected to the idea of "consent.” If the poor person consented to his salary, then his autonomy would be respected, and no rights would be transgressed (Kymlicka 2002, 123). As long as he had the right to say no, he did not really belong to his employer. In this formal way, we can say that he belongs only to himself.

Egalitarians have a different view. For them, poverty and others material limitations should be seen as a kind of coercion. In his situation, the poor person can’t really exercise his autonomy. The actual control of his life implies a minimum of material resources. This is what Kymnlicka calls "substantive self-ownership" (Kymlicka 2002, 122).

Understood this way, the protection of autonomy is not just a matter of refraining from external interventions; it's also a matter of providing substantive conditions for the exercise of this autonomy. Individuals have the right to claim that these conditions are provided. That's what, roughly, Rawls's second principle of justice-which includes the "principle of difference" and the "principle of fair equality of opportunity"-tells us.

This logic legitimates a form of state's intervention that is completely compatible with liberal ideals, for it's not an intervention that threatens personal autonomy. On the contrary, it's made for the sake of personal autonomy. Of course, we could think, in Rawls's case, that this intervention supports the autonomy of some people - the disadvantaged, while the autonomy of the more fortunate is, in fact, disrespected. But it is not that simple. This is precisely the point where Rawls's notion of "ignorance veil” becomes relevant.

Here, Rawls is inspired by Immanuel Kant, who contends that we are autonomous individuals only when our actions are not determined by external and empirical laws. We must only follow the laws we give ourselves, which happens when we are fully rational (Kant 1993, Section III). The way Rawls finds to express this Kantian idea is to suppose that the principles of justice regulating a well-ordered society are chosen behind a veil of ignorance: People don't know the empirical circumstances that particularize their situation in the worldsocial position, power, degree of intelligence, or other talents, and even their psychological propensities. Rawls argues that only in this hypothetical situation are people able to choose, in an autonomous and fully rational way, the principles that will regulate their lives. As he tells us, only then will their choice "express their nature as rational and autonomous agents" (Rawls 1999, 222). In this sense, if some people pay taxes for the benefit of the least advantaged, their autonomy is being fully respected, because they are following principles that they would have autonomously chosen in the original position. ${ }^{2}$

Besides autonomy, Rawls's work also illustrates how some kind of "intervention" is compatible with another — and related—liberal ideal and neutrality: Rawls, in fact, is a famous defender of neutrality, as we can see in his already mentioned "priority of the just," with notions like "overlapping consensus" and "public reason,” in his later book titled Political Liberalism (Ralws 1993, II, lecture 4; lecture 6). The veil of ignorance may be seen, in fact, as a way of ensuring that our choice of principles of justice won't be influenced by any particular conception of the good-thus respecting neutrality. 
We can therefore conclude that the relational dimension of contemporary rights renders the conception of a "state's intervention" perfectly compatible with the liberal ideals of individual autonomy and neutrality. Now we can turn to the next part of our work, analyzing the distinction between a "liberal intervention" and the ones proclaimed by communitarians and republicans authors.

\section{Communitarian and Republican Interventions}

The communitarian's position is well expressed by Michael Sandel's work. In Justice and the Limits of Liberalism, Sandel tries to show that Rawls's "priority of the just" presupposes an untenable conception of the self, the "unencumbered self," which would be previous to its ends (Sandel 1998, I). As Kymnlicka contends, communitarians have three main reasons to believe that this liberal description of ourselves is wrong: a) it is empty; b) it violates our self-perception; c) it ignores our embeddedness in communal practices (Kymlicka 2002, 221). For Sandel, this emptiness is closely related to the neutrality of the state, for both are derived from the priority of the just, which ignores that "all political orders must embody some values” (Sandel 1998, 11).

In his most recent books—Justice, and What Money Can't Buy, Sandel applies these ideas to everyday cases, which can help us to understand which kind of "intervention" would be acceptable in a communitarian state. In both works, he stresses that liberal neutrality impoverishes political life, for it presupposes that we should not bring our personal values and convictions to this field (Sandel 2010, Chapter 10). ${ }^{3}$ One consequence of this impoverishment is that our lives are increasingly governed by impersonal mechanisms, such as the market, which corrupts values that ought to be preserved (Sandel 2012).

Sandel does not make clear whether those values should be protected from the market simply by the interventions of the state; this idea, however, is implicit in several of his arguments, for instance, when he criticizes the legalized killing of animals belonging to endangered species (Sandel 2012, 43). Sandel is clearly stating that this killing simply should not be legalized. The same could be said in the comparison he makes between American and English policies of blood donations: The later-in which payment is forbidden-is, somehow, better than the former (Sandel 2012, 62).

It must be said that Sandel's position is not—neither communitarian's in general—that all problems should be solved by the state in an authoritarian way. When he gives the example of citizens of a Swiss city accepting the storage of radioactive nuclear waste in their community, he stresses the importance of this being influenced by civic spirit. This attitude should stem from a community's sense of shared values, not "because the government told them so;” consequently, Sandel makes it clear that an authoritarian state is not the best way to promote civic spirit (Sandel 2012, 58-59). His point is that the law should enforce some values, hence his critic of the "priority of the just," however, these values must be part of our identities, and continuously addressed through public debate.

In our view, “communitarian's interventions" should not be seen as necessarily more authoritarian that the ones supported by liberal egalitarians such as Rawls. In fact, some of these interventions would be supported by both, as Sandel points out: In several of his examples, he describes two different kinds of reasons by which market logic could be contested: "equality” and "corruption.” Paying for an addicted woman's sterilization, for blood, or for a place in a line or in a congressional hearing can not only be seen as a corruption of certain values (maternity, donation, and civic spirit) but also as a way of exploring social inequality (Sandel 2012, 10). ${ }^{4}$

We may therefore conclude that egalitarian and communitarian authors both support some kind of "state intervention," even if only the former is compatible with liberal ideals. However, the difference between them 
rests mostly in the reasons behind the interventions, for both will often—-though not always—lead to the same results.

We can now turn to the republican view. As previously stated, we'll concentrate on Dagger's Civic Virtues, Citizenship, and Republican Liberalism, in which he discusses the differences and convergences between this position and the liberal one. Departing from the classical distinction between liberalism as focusing on individual rights and personal autonomy, and republicanism as focusing on civic virtue and public responsibility, Dagger argues that, although they are different, there is no real incompatibility between them. His strategy consists in showing that "autonomy" can be understood in a more collective way, while "civic virtue" can be understood in a more individual way. ${ }^{5}$

What is more interesting for our purposes, however, is that this compatibility is possible, according to Dagger, only if we abandon one of the most important premises of liberal thought: the idea of neutrality. As the author says,

Republican liberalism, however, plainly is not neutral in this sense; on the contrary, it is a perfectionist doctrine that prescribes a certain conception of the good for everyone. Hence republican liberalism cannot be a satisfactory form of liberalism. If liberalism must be neutral or agnostic with regard to competing conceptions of the good life, republican liberalism truly is an oxymoron. (Dagger 1997, 175)

Accordingly, Dragger's strategy consists of denying that liberalism can really be neutral. While there is inadequate space to detail Dagger's arguments in this paper, in our view his arguments fail. Neutrality is a distinctive feature of liberalism, since it is derived from the idea of "no intervention," implicit in the very notion of individual rights.

Much like Sandel, Dagger does not explicitly discuss “government interventions,” however, again, we can think that this is implicit in his denial of neutrality. He stresses, for instance, the importance of education in fostering participative citizenship, which is, as we could say, a typical republican view. It is true that he places "educating desires" as an intermediate position between the more radical position of "molding" them and the less stringent and liberal view, for which people's preferences are just given. ${ }^{6}$ However, this difference of degree does not change the fact that education does have a purpose that ought to be supported by the state: to promote autonomy and civic virtue. In any "perfectionist society," as Dagger himself defines republican-liberalism, government' actions will reflect some view about the good, related to a conception of the good life. This can be seen as a kind of "intervention" in the liberal sense, according to Nozick's or Rawls' version of the term. Of course, there can be several levels of intervention, from radical to more acceptable ones, but discussions about degrees are not relevant for us here.

The important point, for us, is to stress the difference between this kind of intervention and the ones compatibles with liberal neutrality, such as Rawls' principles of difference and equal opportunity, related, as we've seen, to the relational dimension of "claim rights.” Despite Dagger's pretentions in showing their compatibility, in our opinion, his work illustrates the opposite; for, according to Dagger, this compatibility is possible only if we abandon one of the most essential premises of liberal thought, neutrality.

When analyzing Sandel's work, we see that the communitarian view of "intervention" often leads to the same results as the egalitarian one. However, our analysis of Dagger's republican position suggests that even if it is possible, those views are still fundamentally different. Interventions based on promoting or preserving substantive conceptions of the good life can't be labeled as “liberal,” even if their results are, in many specific 
cases, identical.

Another interesting way to make a distinction between those opinions is how they view the relationship between the private and public spheres. Republican and liberals conceptions are known for defending a more strict separation between them, while communitarians-who are probably following the Greeks - tend to support some kind of continuity, with the public sphere usually serving as a reference to the private sphere (Rosas 2008, 101). This importance given to public life is a point shared with republicans, while liberal societies are often accused of impoverishing it (Rosas 2008, 96).

\section{A Possible Coexistence}

We can now return to the basic premise of our paper, namely that more recently we've witnessed an increasing intervention of the state in the private sphere; this is evidenced in labor laws, consumer rights, bioethics, and Internet crimes. Can this be explained only by "liberal intervention," relating to claim rights, which focuses on autonomy and a respect for neutrality? It’s difficult to answer this question at this stage, for, as we say, those different doctrines often lead to the same results. If the state forbids sterilization for money of addicted women, for instance, this can be done for the sake of some substantive communitarian value (related to maternity), according to a republican civic spirit, or, as liberal egalitarians argue, as a way to avoid exploring inequalities in people's positions.

However, in our opinion, it's reasonable to suppose that the increasing interventionist role of the state is somehow related to a historical tendency, in the conception of rights, from a strict formal view to a more substantive one. In fact, as we have noted, compared to its initial individualistic notion, "claim rights" are more social, establishing a kind of relationship between people, and this, in turn, is related to a more substantive conception of autonomy and self-possession. The idea, it would seem, is that freedom can't be so formal and individualistic, for it presupposes cooperation, material resources, recognition, and others goods.

The main point, however, is that this tendency-the dissatisfaction with formalist conceptions and the striving for more substantive approaches, persists. After a shift to a relational notion of rights, but still based on neutrality, actual "interventions" of government in the private sphere could be seen as a shift to laws that reflect substantive conceptions of the good life-in short, to communitarian and republican views.

In the field of academia, this tendency is part of the recent revival of communitarianism and republicanism ideas—with the work of Sandel, Alasdair MacIntyre, and Charles Taylor in the 80s, or republican authors like Philip Petit in the 90s, and more recently, John Maynor and Cécile Laborde—as well as the recent attempts to conciliate this views with the liberal one, as we see in Dagger's work.

This tendency could also be present in the legal field, for instance with the growing concern regarding judicial paternalism (Farnsworth 2000; Kronman 1983; Trebilcock 1997; Zamir 1998), especially in relation to labor laws, consumer rights, and Internet regulations. Bioethics is, of course, a rich domain in relation to this issue: The protection of animals and the environment, or the debate about stem cells, is not easily justified by neutrality and the protection of humans' autonomy alone (Singer 2011; Regan 2004). ${ }^{7}$

If our analysis is correct, and this tendency actually exists, then some questions must be raised about the conciliation between liberal premises and the more substantial conceptions of rights. This conciliation was possible in the past with the notion of claim rights; however, it may become increasingly difficult to reach this level of harmonization. As we said before, communitarian and republican's views deny some fundamental premises of liberal thought. 
How should this problem be addressed? One way is to think that this harmonization may be more easily reached in practice, even if not so in theory. Communitarian or republican elements may be tolerated in real societies and governments, even if their fundaments are liberal. Political theory tends to be monistic — everything coherently derived from one supreme principle, but real societies are more pluralists, accepting the coexistence of different values in ways that are not necessarily coherent. An example of this would be the recent problems with government spying-a movement started, perhaps, with George's Bush "patriotic act;" the state must endorse many values and those may be in conflict with one another. Even if the protection of civil rights - like one of privacy — is very important, the government must also protect the lives of its citizens. In some exceptional circumstances, the later may overcome the former. We are not saying that we support this; rather we are only using this example to illustrate how government actions may be based on different values, but not necessarily harmonious ones.

Another contemporary example would be China, where a society based on communist principles increasingly tolerates several capitalist practices. Thus, a country may adopt “mixed models," putting together components of different doctrines, that although incompatible at a theoretical level, may coexist in practice, with a certain tension between them being tolerated.

This phenomenon, in fact, is not so recent: If we think about anti-abortion laws, for instance, very common — more in the past, but still today—in many democratic countries, it is not easy to justify them only by liberal principles. On the contrary, defenders of abortion are often labeled "pro-choice.” Anti-abortion laws, in fact, are usually influenced by religious beliefs. This is a good example which illustrates the point we are making: Even if the overall principles of liberal societies are secular, following the separation between the state and church, it is possible to find laws, in these countries, based on religious beliefs, which are even opposed, in some sense, to the ideals of autonomy and neutrality. Another example would be the sole recognition of monogamous marriages in liberal societies - this clearly favors one way of life over others, and can't be justified only by the priority of the just (Mulhall and Swift 1996, 26-27). Real societies are complex structures, lacking the crystal clear coherence of a political theory.

This is a way to explain how some laws in liberal societies may follow communitarian or republican principles. However, there are other, slightly different, explanations: For instance, instead of seeing a distance between theory and practice, we could elaborate a theoretical approach that takes into account this tension between divergent views—-some kind of "tragic" or "agonistic" conception, inspired by authors like Friedrich Nietzsche. One example of this sort would be the work of Chantal Mouffe: She believes that modern democracies are based on two ideals-liberty and equality, which cannot be harmonized. There will always be a tension between them, which Chantal identifies as being political "left" and "right” wings. Society will be marked by different configurations of power, depending on which of those two ideals, temporarily, takes over (Mouffe 2000).

We can therefore conclude that the dissatisfaction with the emptiness of "formality," that we've mentioned, and the consequent striving for laws based on more substantial values-which is, in our opinion, a contemporary tendency — could lead to the coexistence of liberal principles with laws and actions reflecting values endorsed by a conception of a good life. This can be seen as a "practical incoherence," where some elements that are incompatible with the overall principles are tolerated in some specific cases, or as a sign of an agonistic model of society, where these conceptions are like forces, always present, competing with each other, leading to provisory configurations of power. It is important to note that in this last case, this "taking over" 
would be much more than simply an election. In fact, the nature and relationship of private and public spheres would be, somehow, reconfigured.

\section{Conclusion}

In Chantal's view, the two competing ideals-liberty and equality-are both part of democratic cultures. We could say the same about the communitarian and the republican models that we've discussed. In this sense, their defense of democracy is what they have in common with liberal principles, and this ensures a kind of "high order" coherence between them. Our paper, then, raises two main questions:

Can the increasing intervention of the state in the private sphere be seen as another stage of a process coming from a strict formal to a more substantial conception of rights, and which has already resulted on the notion of "claim rights," and now starts to incorporate elements related to communitarian or republican views? We think the answer is yes.

If so, how can these elements be harmonized with the overall principles of liberal societies? Will they restrict themselves to some specific cases, being "practically tolerated," or will they become strong enough to really compete with the former? This will only be revealed by the passing of time.

\section{Notes}

1.See, for instance, the discussion about liberty in the Two Treatises, Book II, Chapter IV, 22.

2.There are, of course, other more simple arguments about the problem of advancing the autonomy of the least advantaged. Kymnlicka stresses, for instance, that, since "substantive self-ownership" is a matter of degree, the autonomy of the least advantaged is actually being threatened by their lack of resources, while we can't say the same when the more fortunate pay taxes (Kymlicka 2002, 124).

3. In the second edition of Liberalism and the Limits of Justice, he sets Rawls's Political Liberalism as a typical example of this position.

4. The results would be the same in several cases, but not always, for instance in the case of the legalized killing of endangered species: A communitarian could have reasons to forbid it—for there are positive values being corrupted, but it is not so obvious with liberal egalitarians, for people's autonomy is not at stake.

5. Dagger argues that the fostering of autonomy depends on our interdependence to other people (Dagger 1997, 17-18), and that civic virtue can be understood from cooperatives practices under the principle of "flay play" (Dagger1997, 46-47; 110).

6. "For republican liberals, a part of the point of education is to help people live autonomously. Rather than 'carefully molding' desires and passions, then, a republican-liberal education will try to enable people to govern their desires and passions so that they may live as autonomous individuals in community with other autonomous individuals” (Dagger 1997, 117).

7. See our commentary about anti-abortion laws outlined below.

\section{Works Cited}

Dagger, Richard. Civic Virtues: Rights, Citizenship, and Republican Liberalism. Oxford: Oxford University Press, 1997. Farnsworth, Allan. "Promises and Paternalism.” William and Mary Law Review 41.2 (2000): 385-409.

Kant, Immanuel. Grounding for the Metaphysics of Morals. Indianapolis: Hackett Publishing Company, 1993.

Kronman, Anthony. "Paternalism and the Laws of Contracts.” The Yale Law Journal 92.5 (1983): 763-84.

Kymlicka, Will. Contemporary Political Philosophy. Oxford: Oxford University Press, 2002.

Locke, John. Two Treatises of Governments and a Letter Concerning Toleration. Yale: Yale University Press, 2003.

Mouffe, Chantal. The Democratic Paradox. London: Verso, 2000.

Mulhall, Stephen, and Swift, Adam. Liberals and Communitarians, 2nd ed. Oxford: Blackwell Publishing, 1996.

Nozick, Robert. Anarchy, State, and Utopia. Oxford: Blackwell Publishers Ltd, 1974.

Rawls, John. A Theory of Justice, revised edition. Cambridge: Harvard University Press, 1999.

Rawls, John. Political Liberalism. New York: Columbia University Press, 1993. 
Regan, Tom. The Case for Animal Rights. Los Angeles: University of California Press, 2004.

Rosas, João. Handbook of Political Philosopy. Coimbra: Almedina, 2008.

Sandel, Michael. Justice — What's the Right Thing to Do. New York: Farrar, Strauss, and Giroux, 2010.

Sandel, Michael. Liberalism and the Limits of Justice. Cambridge: Cambridge University Press, 1998.

Sandel, Michael. What Money Can't Buy—the Moral Limits of Markets. Cambridge: Cambridge University Press, 2012 (epub).

Singer, Peter. Practical Ethics. Cambridge: Cambridge University Press, 2011.

Trebilcock, Michael. The Limits of Freedom of Contract. Cambridge: Harvard University Press, 1997.

Zamir, Eyal. “The Efficiency of Paternalism.” Virginia Law Review, 84.2 (1998): 229-86. 